\title{
A Brief Review of Scbolarly Events in the Field of Legal History in Ukraine in 2019
}

Keywords: Ukraine, legal status, legal history, legal regulation, punishment, International Association of Law Historians

Słowa kluczowe: Ukraina, status prawny, historia prawa, regulacje prawne, kara, Międzynarodowe Stowarzyszenie Historyków Prawa

During 2019 three conferences of legal history were held in Ukraine and several monographs in the Field of Legal History were published.

\section{Monographs}

The Legal Status of the German Colonists in the South of Ukraine (from the end of the 18th century through 1917) (in Ukrainian: Правове становище німецьких колоністів на Півдні Украӥни [кінець $18 \mathrm{~cm}$. - 1917 р.]) by Oksana Kanienberh-Sandul. ${ }^{1}$ This monograph is a historical-legal analysis of the legal status of German settlers in the southern part of Ukrainian territory from the 18th to the early 20th centuries. It analyses the characteristics of the basic rights and freedoms, which in their content formed the basis of the settlers' privileged legal status. The book covers various economic, cultural, religious, and political rights and freedoms that were secured and guaranteed by the government. The author also analyses the system of state guarantees of economic, cultural, religious, and political rights and freedoms that ensured the preservation of the nationalcultural and confessional identity of the settlers. Particular attention is focused on the

\footnotetext{
${ }^{1}$ Kanienberh-Sandu, Pravove stanovyshche.
} 
issues of legal regulation of military service by the settlers since for some of them it was essential to their decisions to move.

Agricultural Credit in Ukrainian Territories of the Russian Empire in 18611917: Historical-Legal Research (in Ukrainian: Сільськогосподарський кредит на украӥнських землях Російської імперії у 1861-1917 рр.: історико-правове дослідження) by Dmytro Selikhov. ${ }^{2}$ This monograph analyzes the history of legal regulation of agricultural credit in Ukrainian territories of the Russian Empire from the second half of the 19th through the early 20th centuries, and the organisational and legal bases of crediting agricultural producers through local governmental, organisational, and regulatory support for the activities of joint-stock land banks and small credit institutions. The main focus of the monograph is on forms of agricultural credit, such as repurchase operations in accordance with the legislative acts of 1861, as well as the activities of state and joint-stock land banks, small land and state land reclamation, and resettlement lending to the agricultural sector of the country's economy.

Establishment and development of a reconciliation institute on Ukrainian territories - 9th century through 1917 (in Ukrainian: Становлення та розвиток інституту примирення на українських землях [9 cm. - 1917 p.]) by Anna Hryb and Oleksandr Mykhailov. ${ }^{3}$ This monograph examines the process of formation and development of the Institute of Reconciliation in Ukrainian lands in the period of the 9th century through 1917. The peculiarities of restorative justice and reconciliation practices in Kievan Rus and peculiarities of reconciliation in law in the Polish-Lithuanian period, including the Hetmanate, are analyzed. A separate section is devoted to the legal regulation of the institutions of reconciliation in the Ukrainian territories within the Russian Empire.

Legal Regulation of Land Relations in the Province of Tavriya (1783-1917) (in Ukrainian: Правове регулювання земельних відносин у Таврійській губернії [17831917 pp.]) by Eldar Vaniiev. ${ }^{4}$ This monograph explores the main aspects and features of legal regulation of land relations in the Tavriya province, and explores the main directions of redistribution of land holdings in Crimea after the annexation of the Crimean Khanate. The features of the unification of continental and Muslim law and its implications for the legal regulation of land relations are also investigated. The content of the Russian Empire's land policy in the region is described. The publication contains an analysis of the sources of legal regulation of land relations in the Tavriya province, and their mutual influence and enforcement in practice. It also examines the peculiarities of reforms in the field of land relations from the second half of the 19th century into the beginning of the 20th as a result of peasant and Stolypin reforms.

Punishment in the Law of the Ancient World (in Ukrainian: Покарання в праві держав Стародавнього світу) by Yevheniia Lohvynenko and Ihor Lohvynenko. ${ }^{5}$ The author shows some of the characteristic features of the establishment of the institution of punishment and their peculiarities in some countries of the Ancient East and Eastern Mediterranean in Ancient Times. It includes a long term comparative legal analysis of the imposition and use of punishment in different regions and individual states. The

\footnotetext{
2 Selikhov, Silskohospodarskyi kredyt.

3 Hryb, Anna, Mykhailov, Oleksandr. Stanovlennia ta rozvytok.

4 Vaniiev, Pravove rehuliuvannia.

5 Lohvynenko, Lohvynenko, Pokarannia v pravi.
} 
territorial scope of the study covers the states of the Ancient East (Egypt, the AssyroBabylonian state, India, and China) and ancient states (Ancient Greece, Ancient Rome). The book describes the notion, purpose and types of punishment in the Ancient World, and details of the imposition of such punishments as the death penalty, corporal punishment, imprisonment, and conversion to slavery, expulsion, and shameful punishment, and property punishment.

Competitive selection in the Public Service (Historical-Legal Aspects) (in Ukrainian: Конкурс в державній службі [історико-правові аспекти]) by Olena Yefremova ${ }^{6}$. This book conducts a comprehensive analysis of the theoretical and applied aspects of the category of competitive selection in the public service. In the monograph the competitive selection of civil servants in Ukraine is described, the categorical level of the institute for competitive selection of civil servants of Ukraine is identified and analyzed, and the evolution of legal regulation of competitive selection in the system of state service of Ukraine and other countries, and reforms in the Soviet period and today are analysed. Theoretical and legal analyses of the stages and procedures of competitive selection in the system of state service of Ukraine are conducted. Methods and procedures for evaluating candidates for admission to the civil service through the competition are described.

Child custody in Ukraine from the end of the 18th century to the early 20th (in Ukrainian: Опіка над дітьми в Украӥні наприкінщі 18 - на початку $20 \mathrm{~cm}$.) by Olena Kravchenko. ${ }^{7}$ The monograph analyzes the history of the formation and development of child custody policy, including such aspects as the European tradition, the law of guardianship of minors, and how the activities of international and all-Russian congresses violated such policies. The organisation and activity of institutional care institutions for children such as educational and orphanage homes of the Orders of Public Guardianship, children's institutions of the Office of the Empress Mary's institutions, and guardianship of the blind and deaf were also examined.

Cossack Themis: The City Judiciary in the Hetmanate (in Ukrainian: Козаиька феміда: тродське судочинство в Гетьманщині) by Yurii Voloshyn. ${ }^{8}$ This book, using the example of the Poltava City Court, examines the peculiarities of the appearance of the City Courts in the Hetmanate. It examines the composition of the court, the duties of its members, the competence of the court, the role of lawyers in the administration of justice, and the timing of hearings. The nature of the cases before the City Court and the social groups brought before it are examined. It reveals the lawsuit basis and its features.

Ukrainians' Customary law in scholarly research from the 1920s to the early $1930 \mathrm{~s}$ (in Ukrainian: Звичаєве право украӥниів у наукових дослідженнях 1920-x - початку 1930-х років) by Yuliia Krykun. ${ }^{9}$ This monograph is devoted to the study of Ukrainian customary law in the academic works of scholars from the 1920s to the early 1930s. Established on a wide source base and available historiography, a comprehensive systematic analysis of the scholarly heritage of the researchers was carried out, and the basic directions in the study of customs, family traditions and marital relations, and penal customary law, etc. were traced. The book presents the research and analysis of the scholars'

\footnotetext{
${ }^{6}$ Yefremova, Konkurs v derzhavnii.

7 Kravchenko, Opika nad ditmy.

8 Voloshyn, Kozatska femida.

9 Krykun, Zvychaieve pravo.
} 
works on the problems of custom and customary law, the study of ancient historical sources, and the history of the judiciary of Kievan Rus, and the Lithuanian-Polish and the Hetmanate period.

Custom and laws: sources, commentaries, research, Volume 1: Anthropology of cities and urban law in Ruthenian territories from the 14th century to the first half of the 17th (in Ukrainian: Звичай $i$ права: джерела, коментарі, дослідження, T. 1: Антропологія міст і міського права на руських землях у 14 - першій половині 17 століття) by Tetiana Hoshko. ${ }^{10}$ The urban history of the Ruthenian territories of the Kingdom of Poland and the Grand Duchy of Lithuania from the 14th century to the first half of the 17th is analysed in the monograph. The author relies mainly on legal sources such as the Saxon Mirror, the Charter of Jan Lasky, legal treatises of Bartłomiej Groicki, Paweł Szczerbic, and Paweł Kuszewic, the Sejm Constitutions, and location privileges. The book deals not only with citizens' legal notions, but also with their diverse social, denominational, ethnic, and gender identities, phobias and stereotypes, normative and antisocial behavior, views on the foundations of the world order, the notion of an ideal citizen and their place, and status to the authorities and to other states, etc.

\section{Conferences}

In 2019 three specialized historical-legal conferences were held in Ukraine. Two of them were organised by the International Association of Law Historians. The first of them the 40th International Historical-Legal Conference Ukrainian Jurisprudence in the Anthropological Dimension and the European Legal Space: History, Modernity, Perspectives - was held on May 31 - June 1, 2019 in Uman. The second conference - the 41st International Historical-Legal Conference The phenomenon of Ukrainian law: Historical origins and the modern paradigm was held on November 7-10, 2019 at Hlukhiv Pedagogical University.

Also, on November 15, 2019, a one-day International Historical-Legal Conference Topical Problems of the Constitutional and Legal History of Ukraine and the Scientific Legacy of Professor Volodymyr Kulchytsky (to commemorate his 100th birthday) was held at Ivan Franko Lviv National University.

\section{Bibliography}

\section{Monographs}

Hoshko, Tetiana. Zvychai i prava: dzherela, komentari, doslidzhennia, u 2-h tomach, T. 1: Antropolohiia mist i miskoho prava na ruskykh zemliakh u 14 - pershii polovyni 17 stolittia. Kyiv: Krytyka, 2019.

\footnotetext{
${ }^{10}$ Hoshko, Zvychai i prava.
}

Kronika wydarzeń naukowych - Cbronicle of scholarly events 
Hryb, Anna and Mykhailov, Oleksandr. Stanovlennia ta rozvytok instytutu prymyrennia na ukrainskykh zemliakh (9 st. - 1917 r.). Odessa: Phoenix Publishing, 2019.

Kanienberh-Sandul, Oksana. Pravove stanovyshche nimetskykh kolonistiv na Pivdni Ukrainy (kinets 18 st. - 1917 r.). Odessa: National University Odessa Law Academy, 2019.

Kravchenko, Olena. Opika nad ditmy v Ukraini naprykintsi 18 - na pochatku 20 st. Kharkiv: V. N. Karazin Kharkiv National University, 2019, 429 p.

Krykun, Yuliia. Zvychaieve pravo ukraintsiv u naukovykh doslidzhenniakh 1920-kh - pochatku 1930-kh rokiv. Vinnytsia: Janina, 2019.

Lohvynenko, Yevheniia and Lohvynenko, Ihor. Pokarannia v pravi derzhav Starodavnoho svitu. Kharkiv: V. N. Karazin Kharkiv National University, 2019.

Selikhov, Dmytro. Silskohospodarskyi kredyt na ukrainskykh zemliakh Rosiiskoi imperii u 18611917 rr.: istoryko-pravove doslidzhennia. Dnipro: Dnipropetrovsk State University of Internal Affairs, 2019.

Vaniiev, Eldar. Pravove rehuliuvannia zemelnykh vidnosyn u Tavriiskii hubernii (1783-1917 rr.). Lviv: 2019.

Voloshyn, Yurii. Kozatska femida: grodske sudochynstvo v Hetmanshchyni. Kyiv: Kyiv International School, 2019.

Yefremova, Olena. Konkurs v derzhavnii sluzhbi (istoryko-pravovi aspekty). Chernihiv: Desna Poligraf, 2019. 